\title{
EDITORIAL
}

\section{On the International Court of Justice and the Determination of Rules of Law}

\author{
SANTIAGO VILLALPANDO*
}

In the process of selection of articles for the International Court of Justice section at the Editorial Board of the Leiden Journal of International Law (LJIL), we tend to be seduced by those manuscripts which are effective in making use of the jurisprudence of the Court as an instrument to engage in an in-depth examination of substantive legal issues of a general nature. This reflects our conviction - hardly an original one, since it appears to be shared by our entire legal community - that the Court has a fundamental role to play in the advancement of international law as a legal system. It also echoes an idea that is present in the mission statement of our journal, which is conceived as 'a forum for two vital areas, namely international legal theory and international dispute settlement', thus establishing an intrinsic link between them. But how is the Court's contribution to the development of international law to be assessed? And what do we expect from a scholarly piece examining its case law in this respect?

Under its Statute, the Court's function is merely 'to decide in accordance with international law such disputes as are submitted to it' (Article 38, paragraph I) and its decision 'has no binding force except between the parties and in respect of that particular case' (Article 59). ${ }^{\mathrm{I}}$ However, the decisions delivered by the Court, in its capacity as 'the principal judicial organ of the United Nations' (Article 92 of the Charter), also play a central role among the 'subsidiary means for the determination of rules of law' recognized by Article 38, paragraph I(d), of its Statute. In his recent statement at the High-Level Meeting on the Rule of Law, on 24 September 20r2, the President of the Court emphasized that the Court is an important agent for upholding and promoting the rule of law at the international level, in relations between States', since it has 'the important and noble role of determining existing law and rendering justice between States'.

This aspect of the functions of the Court is a matter of recurrent discussion in the legal literature. It has been authoritatively observed, for example, that, if the

Santiago Villalpando is an editor of the journal. He is also legal officer in the Codification Division of the Office of Legal Affairs of the United Nations in New York. The views expressed herein are those of the author and do not necessarily reflect the views of the United Nations. [S.Villalpando@yahoo.com]

I The Court, of course, may also give advisory opinions on any legal question at the request of authorized bodies (Article 65).

2 Statement by HE Judge P. Tomka, President of the Court, available at the Court's official website: http://www.icj-cij.org/presscom/files/o/ı 7 Ioo.pdf (accessed I9 November 2012). 
Court were to put 'emphasis on its status as an organ of the international legal order - exercising the function of jurisdictio, (i.e., stating the law) - rather than, as with arbitration, an organ of the parties or a mere mechanism in their hands whose sole purpose is to settle their dispute', it could better serve as a catalyst and a pivot for the emergence of an international judicial system and contribute to the unity of international law. ${ }^{3}$ Some voices have expressed concern at the Court's tendency towards issuing 'decisions in which the enunciation of legal principles is kept to the minimum absolutely necessary for the disposition of a case', or at the conviction that, 'whenever possible, a case should be disposed of by findings of fact, rather than by reference to broader legal principles'. ${ }^{4}$ On the other hand, as noted by an experienced insider, '[a] dispute is not an opportunity for a judge to set the world right on particular issues of international law; the Court's decisions are of course valued for their contribution to the development of international law; but that is not their primary function'; it would follow that 'surveys of the state of the law on a given point are neither necessary or desirable beyond what is required to uphold or dismiss the relevant claim'. ${ }^{5}$

The fact is that, when they have recourse to international customary law, the judgments of the Court do not often engage in detailed investigations searching for 'evidence of a general practice accepted as law' ${ }^{6}$ The long elaborations contained in the NorthSea Continental Shelfjudgment, on the applicable rules on delimitation of the continental shelf under customary international law, ${ }^{7}$ or in the Nicaragua judgment, on the customary character of the prohibition of the threat or use of force and the principle of non-intervention, ${ }^{8}$ remain rather exceptional. In general, the statements containing the Court's determination of the applicable rules of international law seem as sharp and categorical as a magical spell, surrounded by the mystery of the principle jura novit curia. A few notorious examples would suffice to illustrate this point:

The obligations incumbent upon Albanian authorities consisted in notifying, for the benefit of shipping in general, the existence of a minefield in Albanian territorial waters and in warning the approaching British warships of the imminent danger to which the minefield exposed them. Such obligations are based ... on certain general and wellrecognized principles: namely, elementary conditions of humanity, even more exacting in peace than in war; the principle of the freedom of maritime communication; and

3 G. Abi-Saab, 'Fragmentation or Unification: Some Concluding Remarks', (I999) 3i NYUJILP 929. As noted by the same author, part of the Court's case law denotes a tendency towards the exercise of 'transactional justice', which may have the effect of transforming the significance of its jurisprudence in the development of international law, in the sense that the concrete settlement of the issue would matter more than the general presentation and interpretation of the applicable law (see G. Abi-Saab, 'Cours général de droit international public', (I987/VII) 207 The Hague Academy Collected Courses 27 I-2.

4 T. M. Franck and P. Prows, 'The Role of Presumptions in International Tribunals', (2005) 4 Law and Practice of International Courts and Tribunals 239.

5 H. Thirlway, 'The Drafting of ICJ Decisions: Some Personal Recollections and Observations', (2006) 5 Chinese Journal of International Law 23.

6 Art. 38, para. I(b) of the Statute.

$7 \quad$ North Sea Continental Shelf (Federal Republic of Germany/Denmark; Federal Republic of Germany/Netherlands), Judgment [i 969] ICJ Rep. 3.

8 Military and Paramilitary Activities in and against Nicaragua (Nicaragua v. United States of America), Merits, Judgment [I986] ICJ Rep. I4, notably 97-I I0, paras. I83-209. 
every State's obligation not to allow knowingly its territory to be used for acts contrary to the rights of other States. ${ }^{9}$

... an essential distinction should be drawn between the obligations of a State towards the international community as a whole, and those arising vis-à-vis another State in the field of diplomatic protection. By their very nature the former are the concern of all States. In view of the importance of the rights involved, all States can be held to have a legal interest in their protection; they are obligations erga omnes. ${ }^{\text {IO }}$

... in international law it is firmly established that, as also diplomatic and consular agents, certain holders of high-ranking office in a State, such as the Head of State, Head of Government and Minister for Foreign Affairs, enjoy immunities from jurisdiction in other States, both civil and criminal. ${ }^{\text {I }}$

In these instances, the Court relies on its sole authority to sustain its findings of law. Like any good magician, the Court does not reveal its secrets, but these pronouncements carry a gravitas which directly stems from the status of the Court and its distinguished composition, as well as the elaborate and balanced procedures that regulate the deliberation and drafting of its decisions. The Court - it should be said in passing - is the foremost promoter of the authoritativeness of its own pronouncements: on many occasions, it supports its findings of law with references to its own jurisprudence or that of its predecessor, the Permanent Court of International Justice. On certain occasions, it may appear that the emperor is naked under its new clothes: for example, the careful description of state practice made by the dissenting judges in the Reservations to the Genocide Convention advisory proceedings, supporting the requirement of unanimous consent to reservations, contrasts with the forward-looking, but more impressionistic, reasoning followed by the majority. ${ }^{\mathrm{I2}}$ In any event, the pronouncements of law made by the Court generally become instant classics in our discipline and trustworthy references as to the state of the law.

In recent years, we also find several instances in which the Court has relied on the authority of another United Nations body to support its findings of law, namely the International Law Commission. The watershed precedent, in this regard, is the I 997 judgment in the Gabčikovo-Nagymaros Projectcase, where the Court famously invoked the draft Articles on State Responsibility, adopted on first reading by the Commission, to support its findings on the law applicable to the 'necessity' defence invoked in the proceedings. ${ }^{\text {I3 }}$ The significance of this passage cannot be overstated. The Court had

9 Corfu Channel (United Kingdom v. Albania), Judgment of 9 April I949, [I 949] ICJ Rep. 22.

Io Barcelona Traction, Light and Power Company, Limited (Belgium v. Spain), Judgment, [I 970] ICJ Rep. 32, para. 33.

I I Arrest Warrant of I I April 2000 (Democratic Republic of the Congo v. Belgium), Judgment, [2002] ICJ Rep. 20-I, para. 5I.

I 2 Cf. Reservations to the Convention on Genocide, Advisory Opinion, [I95 I] ICJ Rep. I5, and the dissenting opinion of Judges Guerrero, Sir Arnold McNair, Read and Hsu Mo, ibid., 3 I. As is well known, the majority found that 'a State which has made and maintained a reservation which has been objected to by one or more of the parties to the Convention but not by others, can be regarded as being a party to the Convention if the reservation is compatible with the object and purpose of the Convention' (ibid., 29). According to the dissenting judges, the rule propounded by the majority was supported by 'no trace of any authority in any decision of this Court or of the Permanent Court of International Justice or any other international tribunal, or in any text-book ... [or] in the law and practice of the United Nations' (ibid., 42-3).

I3 Gabčikovo-Nagymaros Project (Hungary/Slovakia), Judgment, [I 997] ICJ Rep. 39-40, para. 50. The Court also referred, without any discussion, to the commentary of the Draft Articles with regard to the definition of 
already referred in the past to the work of the Commission, but in the framework of its investigation on the preparatory works of a convention for the purposes of its interpretation; ${ }^{\mathrm{I} 4}$ it had also occasionally declared the customary character of a rule enshrined in an international instrument, without additional explanation, but with regard to a treaty (such as the Vienna Convention on the Law of Treaties) or a General Assembly resolution (e.g., the Declaration on Friendly Relations). On this occasion, the Court was giving, without reservation, its seal of approval to the provisional conclusions reached by the Commission per se, independently from any convention or resolution. By so doing, it made its own the underlying examination of practice and opinio juris conducted by the Commission, as well as the latter's assessment on the state of customary international law in the field, without any further elaboration.

As mentioned, this is not an isolated instance. In the same r997 judgment, the Court relied on the work of the Commission on several other occasions. ${ }^{5}$ The Court again referred to the Commission's article on necessity (this time, in its final version) in the 2004 advisory opinion on the Legal Consequences of the Construction of a Wall in the Occupied Palestinian Territory. ${ }^{16}$ It also invoked the Articles on State Responsibility and their commentary several times in the 2005 judgment in the Armed Activities on the Territory of the Congo (Democratic Republic of the Congov. Uganda) case $^{17}$ and in the 2007 judgment in the Application of the Convention for the Prevention and the Punishment of the Crime of Genocide (Bosnia and Herzegovina v. Serbia and Montenegro) case, ${ }^{18}$ as well as in the 2010 judgment in the Pulp Mills on the River Uruguay case, ${ }^{19}$ the 2012 judgment in the Jurisdictional Immunities of the State case, ${ }^{20}$

this circumstance precluding wrongfulness, its basis in the general theory of law, its exceptional character in international law, and the enumeration and interpretation of the conditions applicable thereto (ibid., 40-I, paras. 50-52; 4I, para. 53; 42, para. 54; and 45, para. 57).

I4 In other words, these are instances of application of the rule of interpretation embodied in Art. 32 of the Vienna Convention on the Law of Treaties, which the Court considers to be customary in nature. E.g., North Sea Continental Shelf (Federal Republic of Germany/Denmark; Federal Republic of Germany/Netherlands), Judgment, [1969] ICJ Rep. 33-6, paras. 48-55, as part of the study of the preparatory works on Art. 6 of the I 958 Geneva Convention on the Continental Shelf. For recent examples, see Pulp Mills on the River Uruguay (Argentina v. Uruguay), Judgment, [2010] ICJ Rep. 66, para. I4I (on the preparatory works of Art. 57 of the Vienna Convention on the Law of Treaties) or the 2012 judgment in the Jurisdictional Immunities of the State (Germany v. Italy, Greece intervening) case (paras. 55-56, 64, 69, 77, and 89, as part of the preparatory works on the United Nations Convention on Jurisdictional Immunities of States and Their Property, which was itself used as a reference for the determination of the applicable customary law, since the Convention is not yet in force).

I5 Notably, in support of: the statement that, when a state has committed an internationally wrongful act, its international responsibility is likely to be involved whatever the nature of the obligation it has failed to respect (ibid., 38-9, para. 47); the distinction between the actual commission of a wrongful act and the conduct prior to that act which is of a preparatory character (ibid., 54, para. 79); and the conditions applicable to countermeasures under international law (ibid., 55, para. 83).

I6 [2004] ICJ Rep. I95, para. I40.

I7 [2005] ICJ Rep. 226, paras. I60 and 266, 293.

I8 [2007] ICJ Rep. II6, para. I73; 202, para. 385; 207, para. 398; 2I5, para. 4I4; 2I 7, para. 420; 222, para. 43I; and 233, para. 460 .

I9 [20I0] ICJ Rep. I04, para. 273.

20 Jurisdictional Immunities of the State (Germany v. Italy, Greece intervening), Judgment of 3 February 20I 2, paras. 58,93 , and 137 . 
and the 2012 judgment on compensation in the Ahmadou Sadio Diallo case. ${ }^{21}$ In the 2007 judgment on preliminary objections in the last case, the Court declared that the definition of diplomatic protection contained in Article I of the Commission's draft Articles on Diplomatic Protection reflected customary international law. ${ }^{22}$ In the 2010 judgment in the Pulp Mills on the River Uruguay case, the Court invoked the Commission's 200I draft Articles on Prevention of Transboundary Harm from Hazardous Activities as reflection of the applicable rules of general international law on consultations on preventive measures. ${ }^{23}$ In all these instances, the Court's finding that these provisions reflect customary international law is as brief and categorical as its own autonomous determinations of the rules of law, which apparently indicates an increasing trust placed by the Court on the Commission.

Let us now turn to the other side of this relationship. In its work for the codification and progressive development of international law, the International Law Commission also relies heavily on the jurisprudence of the International Court of Justice. The commentary to the Articles on State Responsibility, for example, contains as many as 222 references to the case law of the Court and a further 76 references to that of its predecessor. On several occasions, the judicial decisions of the Court constitute the first critical step in the reasoning that leads the Commission to the determination of the rules of $\mathrm{law}^{24}$ and the Commission usually follows the Court even on controversial issues, such as that of attribution to a State of the conduct of a person or group of persons. ${ }^{25}$ In the case of the codification of the rules on assurances and guarantees of non-repetition, the Commission went to the point of postponing its final determination of the state of the law, preferring to wait for the imminent delivery of the judgment of the Court in the LaGrand case, ${ }^{26}$ which was then emphasized in the final commentary. ${ }^{27}$ The decisive influence of the Court's case law in codification is also apparent in the instruments adopted by the Commission on several other topics, including - to limit ourselves to the most recent work - diplomatic protection, the responsibility of international organizations, the effects of armed conflicts on treaties, etc.

Now, if the Commission relies so heavily on the Court's jurisprudence to determine the rules of law and the Court invokes so indisputably the Commission's work

2 I Ahmadou Sadio Diallo (Republic of Guinea v. Democratic Republic of the Congo), Compensation owed by the Democratic Republic of the Congo to the Republic of Guinea, Judgment of I 9 June 201 2, para. 49.

22 [2007] ICJ Rep. 599, para. 39.

23 [20I0] ICJ Rep. 68, para. I52 (see also 82, para. 203; and 87, para. 215).

24 See, e.g., the commentary to Art. I, 200I YILC, Vol. II (Part Two), at 32-3. See also the commentaries to the provisions on general principles (Art. 2, ibid., at 34; Art. 3, ibid., at 36-7); the breach of an international obligation (Art. I2, ibid., at 54-5; Art. I4, ibid., at 59-60); the responsibility of a state in connection with the act of another state (Chapter IV, Part I, ibid., at 64, and Art. I7, ibid., at 68); circumstances precluding wrongfulness (Chapter V, Part I, ibid., at 7 I; and Art. 22, ibid., at 75-6); the content of responsibility (Art. 3I, ibid., at 9I; Art. 33, ibid., at 94-5; Art. 34, ibid., at 95-6; Art. 35, ibid., at 96-7; Art. 36, ibid., at 98-9; and Art. 39, ibid., at I09-I0); the serious breaches of obligations under peremptory norms of general international law (Chapter III, Part II, ibid., at I IO-I I); the invocation of responsibility (Art. 44, ibid., at I20-I; Art. 46, ibid., at I23; Art. 47, ibid., at I 24; and Art. 48, ibid., at I26); and countermeasures (Art. 49, ibid., at I30). See the commentary to Art. 8 of the Articles on State Responsibility in 200I YILC, Vol. II (Part Two), at 47-9.

26 See the statement of G. Gaja, on behalf of the Chairman of the Drafting Committee, in 200I YILC, Vol. I, at 238-9, para. 63.

27 200I YILC, Vol. II (Part Two), at 90-I. 
for the same purpose, are we not the victims of a normative Ponzi scheme? In other words, what remains of the investigation on 'evidence of a general practice accepted as law' and of the role of governments in the codification of customary international law? The interaction between expert bodies and judicial organs does indeed appear to result in an autocatalytic process ${ }^{28}$ in which the crystallization of opinio juris may occur by the mutual reaffirmation of the existence of a norm, without any external practice. A good illustration of this phenomenon is the saga that brought the rule on necessity from obscurity to the limelight of contemporary international law. In I980, it was not without hesitation that the Commission had included, as a 'safety valve', a provision on this circumstance precluding wrongfulness in its draft Articles: its conclusion that the concept was 'deeply rooted in general legal thinking' was based on instances of state practice and judicial decisions in which the exception was accepted in principle, but had nevertheless never been retained. ${ }^{29}$ As already mentioned, the Court confirmed this interpretation in its I 997 Gabčikovo-Nagymaros Project case by invoking the Commission's work, but without proceeding to any further investigation on the practice (and rejecting the excuse of necessity in the relevant instance). In turn, the I 997 judgment was the only conclusive precedent from the period I980-200I cited by the Commission in its commentary to the final version of this provision. ${ }^{30}$ The Commission's interpretation of the state of the law was confirmed by the Court in the 2004 Wall advisory opinion, which, however, did not invoke any additional element of state practice and, once again, declined to accept the defence in the instant case. While the exception remained thus theoretical, this high-level dialogue had the undisputable effect of shedding light on what was an obscure and untested concept. It certainly played a crucial role in drawing the concept to the attention of the parties and tribunals in the context of investment arbitration, thus paving the way to the first application of the exception of necessity. ${ }^{3 \mathrm{I}}$

This is not problematic in itself. After all, the fact that Article 38, paragraph I(d), of the Statute of the Court refers jointly to judicial decisions and the teachings of the most highly qualified publicists of the various nations may be interpreted as an acknowledgement that their interaction is part of their role as subsidiary means for

28 In chemistry, a reaction is said to be 'autocatalytic' when its own products provoke the catalysis of the reaction. The concept has also been used in social sciences to describe the relationship between the growth in population and that in food production.

29 See i980 YILC, Vol. II (Part Two), 34-52. The quotes are from para. 3I of the commentary ibid., at 49.

30200 I YILC, Vol. II (Part Two), 80-4. The Commission indicates that ' $\mathrm{t}$ ] he plea of necessity was apparently an issue in the Fisheries Jurisdiction case', but also recognizes that the arbitral award in the Rainbow Warrior case had described the Commission's provision on necessity as 'controversial'.

3 I See LG\&E Energy Corp., LG\&E Capital Corp., and LG\&E International Inc. v. Argentina, ICSID Case No. ARB/02/I, Award of 3 October 2006, reproduced in (2007) 46 International Law Materials 36. Other arbitral tribunals in the framework of ICSID have, however, rejected the defence of necessity in the same factual context; see, e.g., CMS Gas Transmission Company v. Argentina, ICSID Case No. ARB/or/8, Award of I 2 May 2005, in (2005) 44 International Law Materials I 205. 
the determination of rules of law..$^{32}$ In the case of the Court and the Commission, there are even certain institutional factors that facilitate this interaction. ${ }^{33}$

The question arises, however, whether the subsidiary character of the work of the Commission and the case law of international tribunals in this area is not being lost. The novelty, in recent years, is that governments seem to be content with letting this autocatalytic process run freely. In the 25 years of existence of LJIL-years which are undoubtedly amongst the most productive in the history of the codification and progressive development of international law - the General Assembly has increasingly adopted the practice of simply 'taking note' of the products of the Commission's work (draft articles, principles, guidelines, studies), waiting for the consolidation of international law in the field. ${ }^{34}$ True, these instruments are usually also 'commended to the attention' of governments, who have the opportunity to make their views known in many ways (at the Sixth Committee, through the consideration of the annual reports of the Commission, and with their own (non-) application of such rules in practice). However, governments appear to be agreeing to downgrade their intervention, by giving up the opportunity of negotiating conventions of codification; in the past quarter of a century, the Assembly has followed up with international treaties only two topics referred to it by the Commission..$^{35}$ Is this an indication of passivity, on their part, with regard to the determination of the rules of law? Tellingly, the resolutions by which the General Assembly has periodically postponed its decision on any future action on the Articles on State Responsibility have been accompanied, since 2004, with a request for the Secretary-General to prepare, and then update, a 'compilation of decisions of international courts, tribunals and

32 Indeed, the French version of this provision uses the expression moyen auxiliaire ('subsidiary means') in the singular: 'Sous réserve de la disposition de l'Article 59, les décisions judiciaries et la doctrine des publicistes les plus qualifiés des différentes nations, comme moyen auxiliaire de détermination des règles de droit'.

33 The required qualifications and election of members of the two bodies are similar. Members of the Court shall possess the qualifications required in their respective countries for appointment to the highest judicial offices or are jurisconsults of recognized competence in international law, and they are elected by the General Assembly and the Security Council (Arts. 2 and 4 of its Statute). The Members of the Commission shall be persons of recognized competence in international law and are elected by the General Assembly (Arts. 2 and 3 of its Statute). It is therefore not surprising that, throughout the history of the two bodies, roughly a third of the Members of the Court have also been Members of the Commission.

34 See: Nationality of Natural Opersons in Relation to the Succession of States (General Assembly Res. 55/I53, 59/34, 63/I I 8 and 66/92); Articles on Responsibility of States for Internationally Wrongful Acts (General Assembly Res. 56/83, 59/35, 62/6I and 65/I9); Fragmentation of International Law: Difficulties Arising from the Diversification and Expansion of International Law (General Assembly Res 6I/34); Allocation of Loss in the Case of Transboundary Harm Arising out of Hazardous Activities (General Assembly Res. 61/36, 62/68 and 65/28); Prevention of Transboundary Harm from Hazardous Activities (General Assembly Res. 62/68 and 65/28); Diplomatic Protection (General Assembly Res. 62/67 and 65/27); Unilateral Acts of States (General Assembly Res. 6I/34); The Law of Transboundary Aquifers (General Assembly Res. 63/I 24); Responsibility of International Organizations (General Assembly Res. 66/Ioo); Effect of Armed Conflicts on Treaties (General Assembly Res. 66/99). Although it could not take action on the Guide to Practice on Reservations to treaties in 20I2, as a consequence of the disruption of the Sixth Committee meetings due to Hurricane Sandy, it is expected that the General Assembly will follow the same practice in their regard at the sixty-eighth session, in 2013.

35 None of which - it should also be noted - has entered into force. These are the I997 Convention on the Law of the Non-Navigational Uses of International Watercourses and the 2004 United Nations Convention on Jurisdictional Immunities of States and Their Property. One could possibly add the I 998 Rome Statute of the International Criminal Court, which contains some codification aspects from the draft Code of Offences against the Peace and Security of Mankind. 
other bodies referring to the articles'. ${ }^{36}$ In other words, the very decision whether to adopt a convention will depend on how the codification is applied in judicial practice.

All this leads us back to the Court. A closer reading of its jurisprudence shows that the Court is very selective in its recourse to the Commission. For example, the Court's devoted reliance on the Commission's work with respect to matters of attribution and necessity contrasts with its hesitation in applying other provisions of the Articles on State Responsibility. The Court has shown some restraint in applying the rules on the content of the international responsibility of a state: it has declared, for instance, that it is only 'in special circumstances' that there was a need for it to recall the obligation to cease a wrongful conduct or to order assurances and guarantees of non-repetition; ${ }^{37}$ and it has often abstained from awarding damages, considering that its declaration of the breach 'constitutes appropriate satisfaction'. ${ }^{38}$ Similarly, in the same judgment on preliminary objections in the Ahmadou Sadio Diallocase which quoted, with approval, the Commission's definition of diplomatic protection, the Court carefully avoided pronouncing itself on the customary character of anothermore controversial - provision of the Articles on Diplomatic Protection, regarding protection by substitution. ${ }^{39}$ There are many other instances in which the Court could have relied on the work of the Commission, but decided to proceed to its own autonomous determination of the applicable law. To take but a couple of examples, in the Avena and Other Mexican Nationals case, the Court's handling of the question whether Mexico could espouse the claims of individuals with double nationality was resolved by the Court without any reference to the Commission's undergoing work on diplomatic protection; ${ }^{40}$ the examination of the legal consequences of the construction of a wall in the Occupied Palestinian Territory, in the 2004 advisory opinion, mirrors the structure and rationale of the Articles on State Responsibility, but without mentioning them and occasionally departing from their rules. ${ }^{4 \mathrm{I}}$ As with many other international tribunals, the Court never goes as far as overtly

36 See General Assembly Res. 59/35 of 2 December 2004; 62/6I of 6 December 2007; and 65/I9 of 6 December 2010.

37 Dispute Regarding Navigational and Related Rights (Costa Rica v. Nicaragua), [2009] ICJ Rep. 267, respectively at paras. I 48 and I 50.

38 See Application of the Convention for the Prevention and the Punishment of the Crime of Genocide (Bosnia and Herzegovina v. Serbia and Montenegro), Merits, Judgment, [2007] ICJ Rep. 234-6, paras. 463, 465, and 469; Certain Questions of Mutual Assistance in Criminal Matters (Djibouti v. France), Judgment, [2008] ICJ Rep. 245, para. 204; Pulp Mills on the River Uruguay (Argentina v. Uruguay), Judgment, [2010] ICJ Rep. I06, para. 282(I).

39 [2007] ICJ Rep. 6i6, para. 93.

40 Compare the Court's judgment ([2004] ICJ Rep. 36-7, paras. 4I-42) with the separate opinion by Judge Parra-Aranguren (ibid., 87-8, paras. I 2-I5).

4I Legal Consequences of the Construction of a Wall in the Occupied Palestinian Territory, Advisory Opinion, [2004] IC] Rep. I96, para. I44. Mirroring the Commission's Articles, the Court deals, in turn, with Israel's obligations to comply with the primary obligation, put an end to the violation of its international obligations and make reparation, either through restitution or compensation, then considering the legal consequences for other states, including the obligations not to recognize the illegal situation resulting from the wrongful act, not to render aid or assistance in maintaining the situation, and to see to it that breaches be brought to an end. The Court envisages certain consequences not explicitly codified by the Commission (such as Israel's obligation to make reparation to natural or legal persons concerned, as opposed to a state) and infers the obligations of all states from the concept of obligations erga omnes and Common Art. I of the Geneva Conventions (as opposed to the concept of jus cogens, as foreseen by Arts. 40 and 4I of the Commission's Arts.). 
contradicting the Commission, but the detours of its reasoning are revealing of its interpretation of customary law.

In sum, to fully assess the contribution of the Court to the development of our discipline, it is not sufficient to analyse in awe the repercussions of its explicit and categorical dicta as to the state of the law. These are only the tip of an iceberg made of implicit choices, silences, and innuendos, which may be understood only by a thorough reading not only of the judgment, but also of the opinions of judges and the pleadings of the parties, in light of the general debates in the legal scholarship of our times. In this regard, it may be asked to what extent one should be nostalgic of those times in which the Court was allegedly more proactive in its role of determination of the rules of law The reading of old judgments shows that the Court has often been concise in its investigations on practice and opinio juris in the past, and that recent judgments still contain significant contributions to general international law (if not always to the satisfaction of all). In this perspective, the legal literature has an important role to play in establishing the link between the Court's jurisprudence and general legal theory, maybe through a better understanding of the interaction of the principal judicial organ of the United Nations and other entities active in our field (the International Law Commission, as illustrated here, and also the many tribunals and monitoring bodies today in activity). We hope that, in accordance with its mission statement, LJIL is a useful part in this debate. 